\title{
JURNALISME SENSITIF BENCANA DALAM MANAJEMEN PENCARIAN, PENGELOLAAN, INFORMASI DAN PEMBERITAHUAN BENCANA DI RUANG REDAKSI
}

\author{
Filosa Gita Sukmono dan Fajar Junaedi \\ Ilmu Komunikasi Universitas Muhammadiyah Yogyakarta \\ Jl. Ring Road Barat, Tamantirto, Kasihan, Bantul, Daerah Istimewa Yogyakarta, 55184. \\ Telp. (0274) 387656 \\ Email : filosa@umy.ac.id dan fajarjun@umy.ac.id
}

\begin{abstract}
The real experience of journalists in the field when disaster coverage is learning that can be researched empirically in disaster coverage in the present and future. The purpose of this research described problems communication disaster experienced by reporters at the disaster, within specific research about experiences journalist who served in Yogyakarta and surrounding when coverage eruption Merapi 2010. Methods used in this research is indepth interviews with the journalists who involved in disaster coverage. The result of this research was found an important aspect that must be controlled reporters, namely, the ability accuracy and verification of data in coverage that puts forward journalism sensitive disasters and as well as to give hope to residents affected disaster and people through journalism optimistic in disaster coverage. The absence of standard operating procedure (SOP) of disaster coverage during the eruption of Merapi Mount eruption in 2010 became a valuable lesson for various media. The SOP of disaster coverage becomes significant in disaster coverage which now has to be prepared by the editor before giving assignments to journalists to cover the disaster. This research contributes to give a new insight for journalist on disaster journalism issue.
\end{abstract}

Keywords: disaster, communication, disaster-sensitive journalism, optimistic journalism

\begin{abstract}
Abstrak
Pengalaman nyata wartawan di lapangan saat liputan bencana merupakan pembelajaran yang bisa dikaji secara empiris dalam liputan bencana di masa kini dan mendatang. Tujuan penelitian ini mendeskripsikan persoalan komunikasi bencana yang dialami oleh wartawan di lokasi bencana, dengan secara spesifik meneliti tentang pengalaman wartawan yang bertugas di Yogyakarta dan sekitarnya saat liputan erupsi Gunung Merapi tahun 2010. Metode yang digunakan yaitu wawancara mendalam kepada para wartawan yang terlibat dalam liputan bencana. Hasil dari penelitian ini adalah ditemukan aspek penting yang harus dikuasai wartawan, yaitu, kemampuan akurasi dan verifikasi data dalam liputan yang mengedepankan jurnalisme sensitif bencana dan sekaligus memberikan harapan kepada warga terdampak bencana maupun khalayak melalui jurnalisme optimis dalam liputan bencana. Belum adanya standar operasi prosedur (SOP) liputan bencana pada saat liputan bencana erupsi Gunung Merapi tahun 2010 menjadi pelajaran berharga bagi berbagai media. SOP liputan bencana menjadi hal yang signifikan dalam peliputan bencana yang kini harus disiapkan oleh redaksi sebelum memberikan penugasan kepada wartawan untuk meliput bencana. Kontribusi penelitian ini adalah wawasan baru kepada wartawan mengenai jurnalisme sensitif bencana.
\end{abstract}

Kata kunci : bencana, komunikasi, jurnalisme sensitif bencana, akurasi, verifikasi

\section{Pendahuluan}

Indonesia merupakan negara yang rentan terhadap bencana alam, dalam berbagai bentuk, mulai dari banjir, gunung meletus, tanah longsor dan gempa bumi. Membicarakan tentang bencana alam maka setidaknya bencana alam bisa dilihat dari beberapa perspektif; yaitu pertama, bencana alam yang terjadi karena faktor alam, seperti gempa bumi dan erupsi gunung berapi. Bencana alam seperti ini tidak bisa dihindari oleh manusia, namun bukan berarti tidak ada yang bisa 
dilakukan oleh manusia. Kemajuan teknologi telah menjadikan manusia semakin tanggap terhadap bencana alam yang terjadi, dimana bencana alam dapat diprediksi dan diantisipasi. Kurangnya kesadaran atas pelestarian ekologi lingkungan menjadi sebab utama terjadinya bencana alam dalam perspektif kesiapsiagaan bencana (Junaedi dan Sukmono, 2017: 3). Kedua adalah bencana nonalam yaitu bencana yang disebabkan oleh kemajuan bencana yang diakibatkan oleh peristiwa atau rangkaian peristiwa nonalam yang antara lain berupa gagal teknologi, gagal modernisasi, epidemi, dan wabah penyakit.

Salah satu bencana nonalam yang menonjol pada tahun 2016 adalah ambruknya Jembatan Kuning di Klungkung, Bali, yang ambruk saat Hari Nyepi Segara, Minggu 16 Oktober 2016. Jembatan ini sebenarnya dikhususkan untuk pejalan kaki, namun dalam perkembangannya juga digunakan untuk sepeda motor sehingga akhirnya tidak mampu menahan beban dan roboh (Junaedi dan Sukmono, 2017 : 3). Ketiga adalah bencana sosial adalah bencana yang diakibatkan oleh peristiwa atau serangkaian peristiwa yang diakibatkan oleh manusia yang meliputi konflik sosial antarkelompok atau antarkomunitas masyarakat, dan teror. Dalam konteks Indonesia, bencana sosial saat ini masih menjadi ancaman serius. Kerusuhan yang terjadi pada Mei 1998, yang kemudian merembet ke berbagai konflik horizontal antarkelompok suku dan agama, seperti yang terjadi di Kalimantan Barat dan Maluku pasca reformasi 1998 membuktikan potensi bencana sosial yang bisa meledak sewaktu - waktu (Junaedi dan Sukmono, 2017: 4-5).

Tahun 2016, bencana alam di Indonesia tercatat sebagai salah satu tahun terburuk dalam sejarah kebencanaan, sebagaimana yang terlihat dalam tabel di bawah ini.

Tabel 1. Bencana yang Terjadi Sepanjang tahun 2016

\begin{tabular}{|c|c|c|c|}
\hline No & Lokasi dan Waktu & Bentuk Bencana & Korban \\
\hline 1. & $\begin{array}{l}\text { Gunung Sinabung di } \\
\text { Kabupaten Karo, Suma- } \\
\text { tera Utara, } 21 \text { Mei } 2016\end{array}$ & $\begin{array}{l}\text { Awan panas yang berasal } \\
\text { dari erupsi Gunung Sinab- } \\
\text { ung }\end{array}$ & $\begin{array}{l}\text { Tujuh orang meninggal dunia dan } 2 \text { orang kritis } \\
\text { dengan luka bakar terkena awan panas bersuhu } \\
700 \text { derajat celsius }\end{array}$ \\
\hline 2. & Purworejo, 18 Juni 2016 & $\begin{array}{l}\text { Banjir bandang dan tanah } \\
\text { longsor melanda daerah } \\
\text { perbukitan di Kabupaten } \\
\text { Purworejo, Jawa Tengah. }\end{array}$ & $\begin{array}{l}43 \text { orang warga di lokasi bencana meninggal den- } \\
\text { gan rincian } 39 \text { meninggal karena longsor dan em- } \\
\text { pat orang meninggal karena banjir di Kabupaten } \\
\text { Purworejo. BPBD Purworejo membuat estimasi } \\
\text { jumlah kerugian akibat bencana banjir dan longsor } \\
\text { yang terjadi sekitar Rp } 15,7 \text { miliar, dengan nilai } \\
\text { kerusakan untuk rumah Rp 4,1 miliar dan infras- } \\
\text { truktur Rp 11,6 miliar. }\end{array}$ \\
\hline 3. & $\begin{array}{l}\text { Garut, Jawa Barat, } 20 \\
\text { September } 2016\end{array}$ & $\begin{array}{l}\text { Sungai Cimanuk yang be- } \\
\text { rada di sekitar Kota Garut } \\
\text { meluap. }\end{array}$ & $\begin{array}{l}\text { Laporan BNPB menyebutkan bahwa } 34 \text { orang } \\
\text { meninggal, } 19 \text { orang hilang, dan } 35 \text { orang terluka } \\
\text { akibat bencana itu. Sementara, sebanyak } 6.361 \\
\text { warga harus mengungsi. } \\
\text { Tercatat sekitar } 2.511 \text { rumah rusak berat dan rin- } \\
\text { gan, serta } 100 \text { rumah hilang akibat tersapu banjir } \\
\text { bandang Garut. Sebanyak } 6.361 \text { orang pun diung- } \\
\text { sikan ke sejumlah lokasi pengungsian }\end{array}$ \\
\hline
\end{tabular}




\begin{tabular}{|c|c|c|c|}
\hline No & Lokasi dan Waktu & Bentuk Bencana & Korban \\
\hline 4. & $\begin{array}{l}\text { Jembatan Kuning di } \\
\text { Klungkung, Bali, am- } \\
\text { bruk saat Hari Nyepi } \\
\text { Segara, Minggu } 16 \text { Ok- } \\
\text { tober } 2016\end{array}$ & $\begin{array}{l}\text { Jembatan Kuning di Klung- } \\
\text { kung, Bali, yang meng- } \\
\text { hubungkan dua pulau kecil, } \\
\text { Nusa Lembongan dan Nusa } \\
\text { Ceningan. ambruksaat Hari } \\
\text { Nyepi karena tidak kuat } \\
\text { menahan beban. Jembatan } \\
\text { ini sebenarnya untuk pejalan } \\
\text { kaki, namun banyak digu- } \\
\text { nakan untuk sepeda motor. }\end{array}$ & $\begin{array}{l}\text { Korban yang terdiri dari } 8 \text { orang tewas dan } 34 \\
\text { luka sudah ditemukan semuanya dan dievakua- } \\
\text { si, termasuk } 17 \text { sepeda motor yang ikut masuk } \\
\text { ke laut }\end{array}$ \\
\hline 5. & $\begin{array}{l}\text { Bandung, Jawa Barat, } 3 \\
\text { November } 2016\end{array}$ & $\begin{array}{l}\text { Banjir terjadi di } 20 \text { titik di } \\
\text { Kota Bandung akibat drain- } \\
\text { ase yang buruk dan sungai } \\
\text { yang meluap. }\end{array}$ & 10 rumah jebol temboknya. \\
\hline 6. & $\begin{array}{l}\text { Kabupaten Pidie Jaya, } \\
\text { Aceh, } 7 \text { Desember } 2016\end{array}$ & $\begin{array}{l}\text { gempa bumi berkekuatan } \\
6,5 \text { skala Richter dengan } \\
\text { durasi } 10-15 \text { detik. }\end{array}$ & $\begin{array}{l}\text { Meninggal } 112 \text { jiwa dan ratusan orang lainnya } \\
\text { terluka. }\end{array}$ \\
\hline
\end{tabular}

Sumber : Junaedi dan Sukmono, 2017 : 6 - 7.

Jurnalisme yang mengabarkan tentang bencana, yang selanjutnya akan disebut sebagai jurnalisme bencana, menjadi perhatian di Indonesia terutama setelah bencana gemba bumi dan tsunami di Aceh tahun 2004 dan erupsi Gunung Merapi di Yogyakarta dan Jawa Tengah pada tahun 2010. Ahmad Arif menuliskan bahwa jurnalisme bencana pada pemberitaan erupsi Gunung Merapi telah diwarnai dengan praktek cemar. Seorang reporter yang berasal dari sebuah stasiun televisi Jakarta salah membedakan suhu panas dan hujan abu dengan awan panas. Akibat kesalahan dalam pemberitaan tersebut terjadi kepanikan, bahkan seorang pengungsi meninggal tertabrak truk akibat suasana panik. Pada tayangan lain, sebuah stasiun televisi yang bersiaran secara nasional, menyebutkan dalam sebuah program infotainment di tanggal 7 November 2010 bahwa Yogyakarta adalah kota malapetaka dan menyebutkan hasil wawancara bahwa pada tanggal 8 November
2010 akan terjadi malapetaka besar di Yogyakarta. Akibatnya kepanikan kembali melanda pengungsi (Arif, 2013: 142 - 143).

Pada konteks erupsi Gunung Merapi tahun 2010, wartawan di Yogyakarta memiliki pengalaman berharga saat peliputan bencana erupsi Gunung Merapi tahun 2010. Erupsi gunung aktif yang berada di perbatasan Daerah Istimewa Yogyakarta dan Propinsi Jawa Tengah ini terjadi dalam periode cukup lama, yang memungkinkan wartawan terjun langsung saat bencana terjadi. Pengalaman berharga lain adalah wartawan di Yogyakarta bukan saja dalam posisi sebagai wartawan yang meliput dan mengabarkan bencana, namun juga mereka terdampak erupsi Gunung Merapi, setidaknya terdampak hujan abu vulkanik.

Pengalaman liputan saat berlangsungnya bencana erupsi Gunung Merapi dimana reporter salah menyebut hujan abu vulkanik sebagai wedhus gembel menjadi pengalaman berharga bagi para wartawan di Yogyakarta. 
Wedhus gembel sebenarnya adalah istilah lokal masyarakat di sekitar Gunung Merapi untuk menyebut awan panas, bukan hujan abu vulkanik. Kesalahan yang dilakukan oleh reporter televisi dalam mengartikan wedhus gembel telah menyebabkan kepanikan warga di sekitar Gunung Merapi. Hal inilah yang melatarbelakangi urgensi penelitian ini, agar komunikasi bencana tidak menjadi bencana komunikasi.

Penelitian terdahulu tentang komunikasi dalam bencana pernah dilakukan oleh Puji Lestari, Sari Bahagiari Kusumayudha, Eko Teguh Paripurno dan Herlina Jayadianti (2016) berjudul Enviromental Communication Model for Disaster Mitigation of Mount Sinabung Eruption Karo Regency of North Sumatra. Penelitian yang mereka lakukan menemukan bahwa komunikasi dalam situasi bencana bersifat rumit dan berhadapan dengan manajemen konflik. Penelitian tersebut menyajikan model komunikasi dengan menggunakan pendekatan kearifan lokal untuk meningkatkan efektifitas komunikasi publik dalam mengatasi manajemen konflik khususnya di wilayah bencana (Lestari, Kusumayudha, Paripurno dan Jayadianti, 2016 : 4265 - 4270). Berbeda dengan penelitian terdahulu, penelitian ini memfokuskan pada bagaimana pencarian dan pengelolaan informasi serta pemberitaan tentang bencana. Temuan penelitian ini diharapkan menjadi model pengembangan jurnalisme sensitif bencana dalam praktek jurnalisme di Indonesia. Penelitian ini bertujuan mendeskripsikan persoalan komunikasi bencana yang dialami oleh wartawan di lokasi bencana, dengan secara spesifik meneliti tentang pengalaman wartawan yang bertugas di Yogyakarta dan sekitarnya saat liputan erupsi Gunung Merapi tahun 2010.

\section{Metode Penelitian}

Penelitian ini dilakukan dalam kerangka penelitian deskriptif kualitatif dengan menggunakan metode studi kasus tentang jurnalisme sensitif bencana dalam pencarian informasi, pengolahan dan pemberitaan bencana di ruang redaksi. Secara lebih spesifik penelitian difokuskan pada pencarian informasi, pengolahan dan pemberitaan bencana erupsi Gunung Merapi di tahun 2010. Bencana erupsi Gunung Merapi terjadi dalam rentang waktu yang cukup panjang, meliputi pra erupsi, erupsi dan pasca erupsi. Rentang waktu bencana ini menjadi pengalaman berharga bagi wartawan yang meliput bencana ini serta redaktur di ruang redaksi. Analisis studi kasus berusaha menjelaskan sebuah realitas sosial secara holistik atau menyeluruh tentang pencarian informasi, pengolahan dan pemberitaan bencana. Peneliti harus bersikap hati-hati dan teliti agar semua realitas yang dilihatnya dapat tercatat dengan baik saat melakukan penelitian.

Metode pengumpulan data dalam penelitian ini adalah dengan wawancara mendalam (in-depth interview) kepada Okto Lamipto (pemimpin redaksi harian Kedaulatan Rakyat), Bambang Muryanto (jurnalis Jakarta Post), Anton Wahyu Prihartono (pemimpin redaksi Harian Jogja), Sulis (jurnalis RBTV), Sirajudin Hasbi (jurnalis Fandom), Dwi Nourma Handito 
(jurnalis Tribun Jogja), Beni Listio (jurnalis radio Sonora FM) dan Lalita Gandaputri (produser MetroTV). Wawancara jenis ini bersifat lentur dan terbuka, tidak memiliki struktur ketat, tidak dalam suasana formal dan bisa dilakukan berulang pada informan. Teknik ini dilakukan pada semua informan. Bagian terpenting dalam wawancara mendalam adalah menanyakan pertanyaan yang ada di panduan wawancara (interview guide) yaitu tentang bagaimana peliputan bencana berbasis jurnalisme sensitif bencana di ruang redaksi dan mengembangkannya ke dalam berbagai pertanyaan serta kemudian mencatat jawaban informan atas pertanyaan yang diajukan secara akurat (Neuman, 2000: 277). Teknik pemilihan informan dapat dilakukan lebih bersifat purposive sampling atau criterion-based selection dengan kriteria informan yang pernah terlibat dalam peliputan dan proses produksi berita tentang bencana.

Setelah data terkumpul, lalu dilakukan analisis dengan prosedur analisis antarkasus (cross-site analiyis) (Neuman, 2000: 32). Analisis seperti ini memungkinkan peneliti untuk mengeksplorasi micro level berupa tindakan individual sampai macro level yang berupa proses dan struktur sosial yang luas (Vaughan dalam Neuman, 2000: 33). Pada setiap kasus terjadi proses analisis model interaktif, dengan tiga komponen yaitu reduksi data, sajian data dan penarikan simpulan atau verifikasi dalam proses siklus (Miles dan Huberman dalam Sutopo, 2002: 186). Reduksi data dalam penelitian ini merupakan bagian proses seleksi, pemfokusan, penyederhanaan dan abstraksi data dari fieldnote. Sajian data merupakan suatu rakitan organisasi informasi, deskripsi dalam bentuk narasi yang memungkinkan simpulan penelitian dapat dilakukan. Sedangkan penarikan kesimpulan perlu diverifikasi agar cukup mantap dan bisa dipertanggungjawabkan (Sutopo, 2000: 90 $-93)$.

\section{Hasil Penelitian dan Pembahasan}

Pada konteks jurnalisme, jurnalisme bencana di Indonesia, peliputan bencana menjadi persoalan yang mengemuka. Persoalan itu berkisar tentang peliputan bencana yang tidak memiliki sensitivitas terhadap korban bencana seperti yang terjadi pada liputan televisi yang mengambil gambar korban bencana dengan cara pengambilan gambar dengan teknik zoom in, medium close up dan close up. Cara pengambilan gambar yang dianggap telah mengkomodifikasi penderitaan korban bencana. Persoalan lain adalah tentang akurasi pemberitaan tentang bencana, baik penggunaan istilah kebencanaan maupun geografi lokasi bencana. Data - data yang didapatkan dari para jurnalis dan redaktur berikut ini menunjukan persoalan dan tantangan di lapangan dalam peliputan bencana.

Persoalan dan tantangan pertama adalah akurasi. Menurut pada informan penelitian, seharusnya wartawan mampu membuat konten yang mampu mendorong korban bencana bisa bangkit dari musibah yang mereka alami. Akurasi data dalam setiap liputan bencana harus menjadi perhatian utama bagi setiap wartawan. Berdasarkan pengalaman wartawan, persoalan akurasi ini terjadi karena tuntutan untuk memberitakan informasi bencana secara cepat. Tuntutan 
kecepatan ini berkaitan dengan keinginan wartawan untuk mengabarkan lebih cepat kepada publik dan sekaligus lebih cepat daripada media yang lain.

Persoalan kedua adalah sumber informasi tentang bencana. Kondisi saat erupsi Gunung Merapi tidak bisa disamakan dengan saat ini, dimana pada masa sekarang Badan Nasional Penanggulangan Bencana baik di tingkat pusat dan daerah bisa menjadi sumber informasi primer. Pada saat erupsi Merapi tahun 2010, sumber informasi primer berasal dari pejabat pemerintah dan korban di lokasi bencana. Pada saat yang bersamaan pada masa itu, media sosial sudah mulai menggeliat dan belum dikelola dengan baik oleh pemerintah. Media sosial secara umum dikelola oleh publik, baik akun pribadi maupun komunitas. Melalui media sosial, informasi tentang bencana disebarkan dan menjadi viral. Media massa harus berhadapan dengan entitas baru bernama media sosial. Beberapa informasi tentang kebencanaan yang berasal dari media sosial diolah oleh media massa sebagai berita, meskipun kemudian terjadi potensi ketidakakuratan informasi.

Potensi ketidakakuratan informasi, bukan alasan media sosial tidak bisa dimanfaatkan dalam simbiosis mutualisme dengan media massa. Kemajuan teknologi komunikasi berbasis internet telah memungkinkan berkembangnya jurnalisme warga (citizen journalism) berbasis media sosial. Media massa arus utama (mainstream mass media), baik dalam bentuk media cetak maupun media elektronik, bisa memanfaatkan informasi bencana dari jurnalisme warga dengan terlebih dahulu harus mengenal karakteristik media sosial. Penguasaan literasi media sosial menjadi aspek penting sebelum menggunakan jenis media baru ini sebagai sumber informasi bencana.

Pada kasus erupsi Gunung Merapi terjadi fenomena unik dalam pengelolaan informasi bencana dimana sumber informasi primer yang menjadi rujukan wartawan adalah pemimpin informal yang menjadi juru kunci Gunung Merapi. Namanya sangat terkenal di media massa yaitu Marijan, yang akrab dikutip media massa dengan sebutan Mbah Marijan. Mbah adalah sebuah kosakata Bahasa Jawa yang berarti Kakek, sedangkan juru kunci adalah abdi dalem (pegawai kraton Kasultanan Yogyakarta). Mbah Marijan adalah figur populer ketika terjadi erupsi Gunung Merapi. Sebagai juru kunci Gunung Merapi, Mbah Marijan memiliki nilai berita tinggi terutama setelah menolak turun dari rumahnya di kawasan bencana. Akhirnya Mbah Marijan meninggal terkena awan panas Gunung Merapi. Bagi wartawan, berita yang bersumber dari perkataan Mbah Marijan memiliki nilai berita yang tinggi mengingat ketokohannya dalam konteks kearifan lokal di sekitar Gunung Merapi.

Menurut pada informan, sumber informasi yang paling bisa dipercaya adalah rilis pers dari lembaga pemerintah yang berwenang pada persoalan bencana. Untuk itu secara ideal, informasi bencana yang diolah di ruang redaksi terutama adalah informasi yang berasal dari rilis pers lembaga yang berwenang. Akurasi informasi dari rilis pers bisa dipertanggungjawababkan 
validitasnya. Dalam konteks bencana, pemerintah memiliki fungsi asistif atau penolong, yaitu menyangkut pemberian bantuan yang diperlukan warga yang terdampak bencana (Lucida, 2013: 43). Fungsi ini seharusnya dipahami secara lebih luas yaitu pemberian bantuan informasi tentang bencana kepada media massa untuk disebarluaskan ke masyarakat. Tujuannya tentu saja adalah mitigasi bencana untuk masyarakat agar tidak jatuh korban.

Persoalan tentang akurasi dan sumber informasi yang menjadi pokok persoalan yang dihadapi wartawan di Yogyakarta saat meliput erupsi Gunung Merapi berkelindan dengan prinsip verifikasi dalam jurnalisme. Keberadaan rilis pers, informasi dari warga di lokasi bencana serta dari media sosial dalam peliputan bencana harus dilihat dalam perspektif verifikasi. Prinsip verifikasi menjadi poin penting yang disampaikan secara implisit oleh wartawan dan redaktur. Ini berarti, wartawan dan redaktur harus menjaga informasi pemberitaannya agar tidak terjadi kepanikan dan ketakutan. Jangan sampai publik yang dirundung kemalangan semakin dilanda kepanikan dan ketakutan akibat produk jurnalisme "isi" yang tidak jelas kebenarannya (Badri, 2011: 156). Verifikasi ini bisa dilakukan dengan melakukan cross check berbagai informasi yang berasal dari beragam sumber tersebut. Semakin informasinya sama, maka informasi semakin valid dan akurat. Sebaliknya jika terjadi perbedaan informasi dari berbagai sumber informasi maka validitas dan akurasi berita perlu dipertanyakan.

Wartawan yang menjadi informan penelitian ini mengakui bahwa wartawan terkadang sangat lemah dalam proses verifikasi data, baik itu dalam kasus bencana alam maupun bencana sosial. Hal ini terjadi karena wartawan terlalu banyak bertumpu dengan second opinion yang hal tersebut biasanya justru malah tidak benar.

Ketelitian dalam melakukan verifikasi informasi menjadi sangat penting agar tidak terjadi bencana informasi. Fakta terjadinya kekeliruan informasi dalam pemberitaan bencana di televisi ini menjadi pembelajaran yang berharga bagi dunia jurnalisme di Indonesia. Sebuah fakta ironis adalah adanya fakta terutama media di Indonesia, ada persoalan media dimana media di Indonesia juga belum memiliki standar operasional yang jelas saat meliputbencana (Arif, 2010:34). Verifikasi dan ketelitian menjadi hal yang harus diperhatikan dalam jurnalisme sensitif bencana.

Persoalan dan tantangan ketiga adalah kemampuan wartawan mendapatkan dan mengola informasi tentang peta bencana. Pemahaman yang baik tentang peta bencana harus diperhatikan media agar jangan sampai mereka justru malah memperburuk suasana, menambah kesedihan dan penderitaan korban bencana. Jangan membuat pembaca berita khawatir dengan berita-berita yang diterbitkan. Peta bencana ini berkaitan dengan istilah kebencanaan, jalur evakuasi dan kondisi masyarakat. Ketidakmampuan wartawan dalam memahami peta bencana berpotensi mengakibatkan bencana sosial. Para wartawan di Yogyakarta yang menjadi informan penelitian ini menyebutkan bahwa bencana sosial itu justru banyak dipicu oleh media massa. Hal itulah yang menjadi alasan mereka menyebutkan pentingnya jurnalisme sensitif 
bencana yang didasarkan pada kehati-hatian mengenai akurasi dan verifikasi informasi secara baik agar tidak terjadi bencana sosial.

Pada pelaksanaan proses peliputan berita, hal yang menjadi pedoman dalam kerja wartawan ada standar operasional prosedur (SOP) yang menjadi acuan kerja. Sayangnya standar yang ada selama ini adalah standar operasional prosedur pada kondisi normal. Berdasarkan penuturan para informan, pada saat erupsi Gunung Merapi tahun 2010, belum ada SOP tentang peliputan bencana. Menurut pengakuan mereka, redaktur di ruang redaksi dan wartawan yang berada di lapangan pada saat itu cenderung untuk melakukan improvisasi pada saat peliputan bencana.

Hal ini semakin pelik ketika informasi bencana harus disiarkan secara langsung dalam format audio-video. Stasiun televisi yang menyiarkan langsung bencana memiliki tantangan terbesar dalam format siaran langsung (live on camera) pemberitaan mengenai bencana. Rapat redaksi merupakan aspek penting dalam penentuan kebijakan mengenai bagaimana format siaran langsung ini dilakukan.

Pada sebuah stasiun televisi, rapat redaksi ini dibutuhkan untuk membahas beragam kebutuhan yang berkaitan dengan aspek kebutuhan tayangan, menyangkut isu yang ditampilkan sampai dengan strategi dan penugasan agar akurasi data memiliki aktualitas yang tinggi. Selain itu dapat dikontribusikan pada pemilihan urutan berita yang layak dan perlu disiarkan. Rapat redaksi dihadiri oleh para pelaksana redaksi dan pelaksanaan siaran terkait, yang meliputi pemimpin redaksi, redaktur pelaksana, produser eksekutif, produser, presenter, pengarah acara, koordinator juru kamera serta koordinator editor. Keputusan yang diambil dalam rapat, selanjutnya akan diteruskan kepada masing-masing unit pelaksana terkait (Indrajaya, 2011: 123).

Terkait relasinya dengan informasi bencana, rapat redaksi harus mempertimbangkan informasi terbaru (update) dari lokasi bencana. Hal ini berkaitan dengan keperluan pemberitaan maupun untuk mengetahui kondisi di lokasi bencana agar keselamatan wartawan yang dikirimkan ke lokasi bencana terjaga. Redaksi bertanggung jawab atas keselamatan wartawannya yang diturunkan di lokasi bencana, bagaimanapun juga tidak ada nyawa yang lebih berharga daripada berita.

Di lokasi bencana, wartawan televisi yang berperan penting adalah reporter dan juru kamera. Bersama produser lapangan, mereka menjadi ujung tombak dalam pencarian informasi bencana baik yang disiarkan secara tunda maupun disiarkan secara langsung.

Reporter sangat berperan dalam salah satu tahapan proses produksi, pencarian berita yang dilakukan bersama dengan juru kamera. Kedua belah pihak harus mampu bekerja sama dengan baik agar tujuan dari peliputan dan reportase dapat tercapai secara maksimal. Jika reportase dilakukan tidak secara langsung, maka setelah melakukan peliputan, reporter menulis naskah yang disesuaikan dengan pengambilan gambar yang didapatkan oleh juru kamera agar menjadi content beritanya (Indrajaya, 2011: 123). Pada saat inilah kerjasama antar reporter di lapangan dan di studio menjadi penting dan yang paling penting adalah bahwa standar 
keselamatan wartawan yang berada di lokasi bencana merupakan prioritas.

Penelitian terdahulu yang dilakukan oleh Tri Hastuti Nur Rochimah dan Fajar Junaedi (2014) berjudul Peliputan dan Reportase Televisi di Lokasi Bencana : Belajar dari Erupsi Merapi 2010 menemukan bahwa reportase televisi secara langsung dari lokasi bencana memiliki tingkat kesulitan yang tinggi dibandingkan dengan reportase televisi di lokasi lain dan dibandingkan dengan liputan media non televisi. Situasi yang tidak menentu dan ancaman terhadap keselamatan jurnalis televisi menjadi persoalan yang mengemuka dalam reportase langsung televisi.

Berdasarkan dengan temuan penelitian terdahulu, dalam liputan langsung di televisi, kondisi yang disampaikan adalah tentang keadaan di lokasi bencana, hal penting yang ditekankan oleh para wartawan yang langsung terlibat dalam peliputan bencana erupsiGunung Merapi adalah pentingnya memberikan perspektif optimis kepada korban bencana dan menunjukan rasa empati kepada korban di lokasi bencana yang diwujudkan dalam pengolahan informasi kebencanaan. Berbagai informasi yang diterima dari berbagai sumber berita, baik itu dari lokasi bencana, rilis berita dan media sosial harus diolah agar data yang disajikan valid dan akurat.

\section{Simpulan}

Sebagaimana tujuan penelitian ini yang hendak mengetahui pencarian informasi, pengolahan dan pemberitaan bencana, maka penelitian ini menyimpulkan bahwa wartawan yang meliput erupsi Gunung Merapi di tahun 2010 mengakui adanya kelemahan dalam praktek jurnalisme bencana yang terjadi saat itu. Persoalan dan tantangan yang mengemuka berkisar tentang akurasi dan verifikasi informasi bencana serta sumber informasi bencana dan pemahaman tentang peta bencana. Alih-alih pemberitaan bencana memberikan perspektif optimis pada korban bencana, pemberitaan bencana justru menghasilkan kepanikan di masyarakat, bahkan terjadi bencana sosial yang menjadi efek domino dari pemberitaan bencana yang dibingkai dalam jurnalisme air mata. Istilah jurnalisme air mata ini digunakan oleh wartawan di Yogyakarta untuk merujuk praktek jurnalisme yang mengeksploitasi korban bencana.

Demi menjaga manajemen pemberitaan selalu dalam koridor jurnalisme sensitif bencana, maka setiap redaksi media sebaiknya menyusun Standar Operasi Prosedur (SOP) peliputan bencana. SOP ini bisa berbeda - beda setiap media, namun benang merah dari SOP yang disusun adalah harus mengedepankan jurnalisme sensitif bencana dan menjauhi praktek jurnalisme air mata. Prinsip jurnalisme sensitif bencana ini meliputi akurasi informasi, verifikasi informasi dan sumber informasi, pemahaman tentang peta bencana, dan keselamatan wartawan di lokasi bencana.

\section{Daftar Pustaka}

Arif, Ahmad. (2010). Jurnalisme Bencana, Bencana Jurnalisme. Jakarta: KPG

Arif, Ahmad (2011). Jurnalisme Bencana : Tugas Suci, Praktik Cemar, dalam Budi, Setio [ed] (2011). Komunikasi Bencana. Yogyakarta :Aspikom

Badri, M (2011). Paradigma Jurnalisme Bencana, dalam Budi, Setio [ed] Komunikasi Bencana. Yogyakarta :Aspikom dan Buku Litera 
H.B. Sutopo. (2002). Metodologi Penelitian Kualitatif. Surakarta : UNS Press. Hessel Nogi .S T. 2005. Manajemen Publik. Jakarta : PT. Grasindo

Indrajaya, DoddyPermadi. (2011). Buku Pintar Televisi, Bogor : Ghazali Indonesia

Junaedi, Fajar dan Filosa Gita Sukmono. (2017). Jurnalisme Sensitif Bencana, Panduan Peliputan Bencana. Yogyakarta, Buku Litera

Lestari, Puji; et. all. Environmental Communication Model for Disaster Mitigation of Mount Sinabung Eruption, Karo Regency of North Sumatera, Journal Information, Volume 19, Number 9 (B) pp 4265-4270, ISSN 1343-4500, eISSN 1344-8994, C2016. Tokyo: International Information Institute.
Lucida (2011). Pemimpin Indonesia dalam Penanganan Bencana, Sebuah Refleksi tentang Kesigapan Pemimpin Indonesia Menghadapi Bencana, Paradigma Jurnalisme Bencana, dalam Budi, Setio [ed]. Komunikasi Bencana. Yogyakarta: Aspikom dan Buku Litera

Neuman, Lawrence (2000). Social Research Methods : Qualitative and Quantitative Approaches, 4th Edition. London :Sage

Rochimah, Tri Hastuti Nur dan Junaedi, Fajar (2014). Peliputan dan Reportase Televisi di Lokasi Bencana : Belajar dari Erupsi Merapi 2010, Jurnal Communication Spectrum, Volume 4 No. 1 Februari Juli 2014. 